\title{
The rhetorical strategies of the Quran
}

\author{
Kusen ${ }^{a, 1^{*}}$, Zainal Rafli ${ }^{b, 2}$, Emzir ${ }^{c, 3}$ \\ ${ }^{a}$ Pendidikan Bahasa, Pascasarjana, Universitas Negeri Jakarta \\ ${ }^{\mathrm{b}}$ Pendidikan Bahasa, Pascasarjana, Universitas Negeri Jakarta \\ ${ }^{c}$ Pendidikan Bahasa, Pascasarjana, Universitas Negeri Jakarta \\ 1ksbhsindonesia@gmail.com dan kusen_pbI3s3@mahasiswa.unj.ac.id*; zainal.rafli@unj.ac.id; emzir.unj@unj.ac.id \\ *korespondensi penulis
}

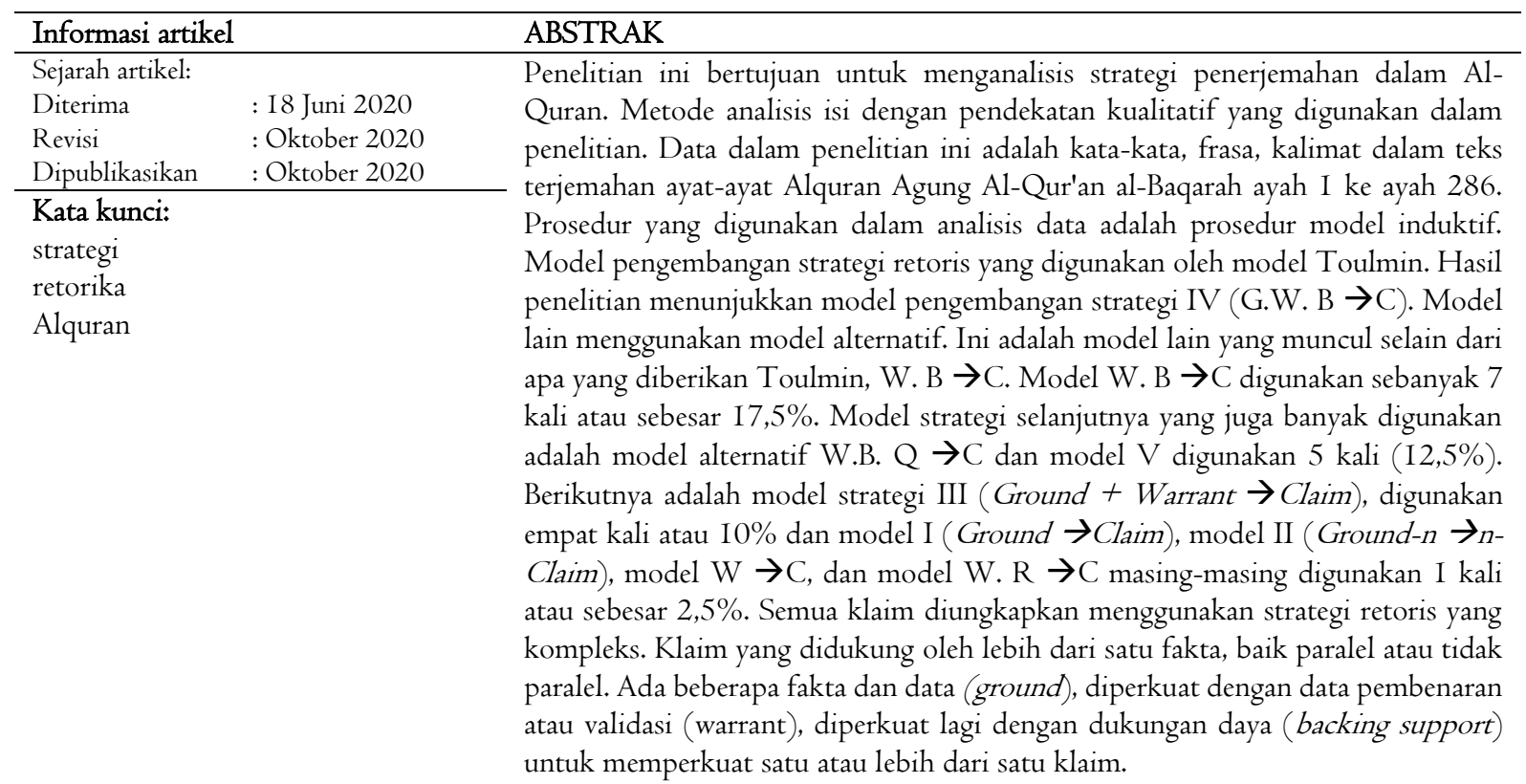

Key word:

strategy

rhetoric

the Holy Qur'an

\begin{abstract}
This research was aimed to analyze translation strategies in the Quran. The content analysis method with the qualitative approach used in the research. The data in this study are words, phrases, sentences in the text of the translation of the ayahs of the Glorious Qur'an surah Albaqarah ayah I to ayah 286. The procedure applied in the analysis of the data is the inductive model procedure. The development model of the rhetorical strategies used by Toulmin model. The results showed the model development strategies IV (G.W. B $\rightarrow$ C). The other model used the alternative model. It is another model appeared aside from what Toulmin has given, W. B $\rightarrow$ C. Model W. B $\rightarrow$ C is used as much as 7 times or of I7.5\%. The next strategy model that also is a widely used is alternative models W.B. $\mathrm{Q} \rightarrow \mathrm{C}$ and the model $\mathrm{V}$ is used 5 times (I2.5\%). Next is the model of strategy III (Ground + Warrant $\rightarrow$ Claim), used four times or by $10 \%$ and the

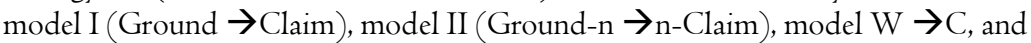
model W. $\mathrm{R} \rightarrow \mathrm{C}$ each used I time or amounting to $2.5 \%$. All of the claims are expressed using complex rhetorical strategies. A claim supported by more than one fact either parallel or not parallel. There are few facts and data (ground), reinforced with a justification or validation data (warrant), reinforced again with power support (backing support) to strengthen one or more than one claim.
\end{abstract}

\section{Copyright (C) 2018 Universitas Ahmad Dahlan. All Right Reserved}

\section{Introduction}

The Quran has a very important role in the life of mankind, especially for Muslims. The Qur'an is believed and used as sources of law in life and the central source of Islamic belief (Opiyo-Omolo, 2004) and the Quran is beautiful text (Ibrahim, Ibrāhīm, Ibrahim, Aydelott, \& Kassabgy, 2000). Oliver 
Lehman emphasized that the Koran is the primary source of inspiration and plays a very central role for one of the major religions in the world and followed by more than one billion people. (Leaman, 2006). urthermore, Quraish Shihab said that the Koran is like a jewel that emits different lights according to their respective perspectives (Shihab, 1996). Therefore, Muslim is obligatory to recite, understand, and practice the teachings in the Qur'an, because the Qur'an is intended for humans, the messages of the Qur'an delivered by God, are full of rhetoric so that humans can capture messages properly and correctly. Rhetoric in the Qur'an touches the physical (means), ratios (reasoning), and emotions (feelings and images) of humans at once. It is hoped that humans can more easily understand and comprehend what Allah almighty said to his servants.

The ability of rhetoric is the ability to use language to understand, develop, communicate ideas and information and to interact with others (Kurylo, 20I2). As stated Murthy \& Ghosal (20I4) rhetoric is a technique using language as art (the beauty of Quran language) both orally and in writing, the beauty of Quran language and style is itself considered a proof of the divine origin of text (Nelson, 200I). In addition to aspects of the beauty of language, rhetoric also emphasizes the use of good reasoning. The arguments put forward in rhetoric aim to strengthen and convince the ideas put forward so that claims or goals are expected to be and are believed by others. James A. Herrick that the purpose of rhetoric is persuasion, clarity, beauty, or mutual understanding. The art of rhetoric can make symbols in the form of language used more persuasive, beautiful, easy to remember, strong, wise, clear, and thus more interesting (Herrick, 2017)

As the three principles of rhetoric put forward by Aristotle namely logos, ethos, and pathos (Tessuto, Bhatia, \& Engberg, 2019). Logos emphasizes the importance of logic or reasoning in delivering arguments, while ethos views the importance of maintaining norms or ethics in conducting conversations or writing with the audience or reader, and pathos focuses more on the factor of emotional involvement between the speaker or writer with the listener or reader (Duke, I990).

The principles of rhetoric stated above give us an understanding that the purpose of rhetoric is closely related and necessary (I) the variety or type of development of rhetoric in text (2) methods of developing rhetoric in text (3) strategy that is a careful planning in using and developing reasoning (logic) in the form of argumentation accompanied by logical reasons presented in the material (text) arranged coherently, and (4) the use of rhetorical tools in the form of the right choice of words, interesting sentences, and beautiful language style so that the listener or reader is involved both thoughtfully and emotionally.

Based on the various explanations above, this study was aim to do the research on the use of rhetorical strategies in the text translation of the Qur'an, Surah al-Baqarah verses I to paragraph 286.

\section{Method}

The method used in this research is content analysis with a qualitative approach. Content analysis is a research technique for making replicable and valid inferences from texts (or other meaningful matter) to the contexts or their use.” (Krippendorff, 2013). What Krippendorff stated content analysis is a research technique for making valid and replicable conclusions from a text in the context of its use.

The data collection technique includes observation and the text documents of Quran. In line with Moleong, (2009) using the content analysis method, the researcher directly observes, sorts, analyzes, and interprets the data until conclusions are reached. The data are words, phrases, sentences in the text of Q.S Albaqarah to 286. The corpus of data is words, phrases, and sentences in the text of the translation that represent the elements of rhetoric. The data analysis used the flow by Mayring (2004) which was divided into two types of procedures, namely the inductive and deductive models. The procedure applied to this study is an inductive model procedure.

\section{Results and Discussion}

The data findings of the rhetorical strategy in the text of the translation of the Qur'an Albaqarah presented in the following diagram:

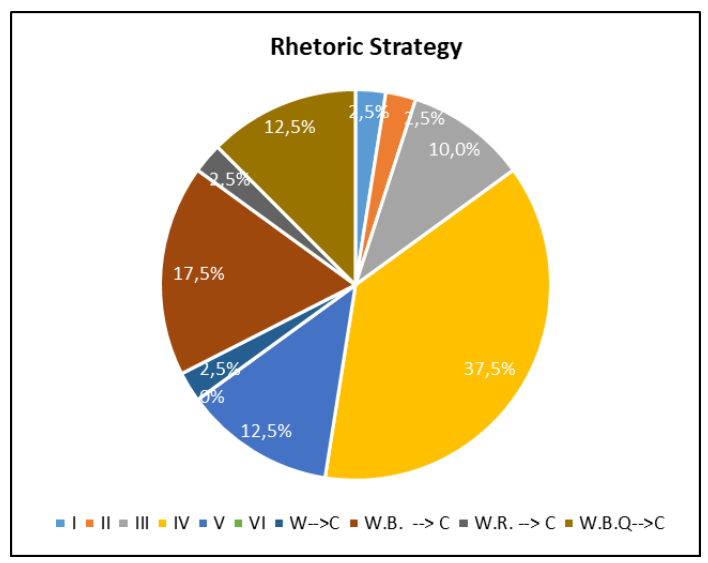

Pictue: Diagram Rhetoric Strategy 
Based on the information from the diagram above, it can be explained that the rhetorical strategy model was most widely used in the translation of the Qur'an text of the Albaqarah letter is the IV development strategy model as Toulmin developed G.W.B $\rightarrow$ C (ground, warrant, and backing support claim). This strategy model is used I5 times or $37.5 \%$ of the total 40 data. The second rhetorical strategy model was widely used as an alternative model, which is another model that appears in addition to what Toulmin exemplifies, namely W.B $\rightarrow$ C (warrant and backing support claim). Model W.B $\rightarrow$ C this is used 7 times or as large $17,5 \%$. The next strategy model that is also widely used is an alternative model W.B.Q $\rightarrow$ C (warrant, backing, dan qualified support claim) and model $\mathrm{V}$ each is used 5 times (I2,5\%). Next is the strategy development model III (Ground + Warrant $\rightarrow$ Claim), used 4 times or as large I0\% and model I (Ground $\rightarrow$ Claim), model II (Ground$\mathrm{n} \rightarrow$ Claim-n), model $\mathrm{W} \rightarrow \mathrm{C}$, and model W.R $\rightarrow \mathrm{C}$ each used I time or $2.5 \%$ each.

Based on the data, the strategy model used it can be explained that the rhetorical strategy in delivering all claims (100\%) uses complex strategies. McCrimmon said that in its simplest form an argument consists of two statements, namely a premise and a conclusion. In a complex form can consist of more than two statements or better, which are parallel, or which are not parallel. (James M. McCrimmon, 1992). That is, a claim is not only supported by one fact. However, one claim is supported by more than one fact, both parallel and not parallel. There are even some facts and data (ground), strengthened by justification or data validation (warrant), reinforced by the other carrying capacity (backing support) to strengthen one or more claims.

This gives an understanding that to put forward a claim (order, solicitation, prohibition) or more, the text of the Koran presents several facts and data (Ground), justification or strengthening of facts (Warrant), and other support (Backing support) that strengthens the claim (Claim) the. This provides an understanding that the Koran has shown a very good line of reasoning and has met the criteria of a reasoning as stated by Warnick and Inch that reasoning has three main elements, namely (I) stance, (2) evidence, and (3) inference. (Warnick, 200I).

The complex argument development strategy used in the Quran shows that every claim or position is always supported by evidence. It is intended to the claims/positions (in the form of orders, prohibitions, invitations, etc.) can be accepted by the speaker partners (Warnick, 200I).
The following describes several examples of argumentation strategies in the Qur'an surah AlBaqarah.

Text-2 bowing data is a text that contains a description of the character of a hypocrite. Character, both in terms of outward and inward (verses: 8-I0) and in terms of words and deeds (verses: II-I2). This is used as a ground or facts. The characteristics of hypocrites are illustrated again by God either accompanied by direct examples of their actions or through metaphors that illustrate the character of hypocrites (verses: 12-20), as backing support (reinforcing with other information / other supporting facts) and as warrant (reasons which reinforce the facts). This ground or fact, backing support, and the warrant is submitted by Allah to strengthen the claim in the first bowing. The second bowing reinforces the claim that the Quran is guidance for the righteous, but not for those who disbelieve and those who are hypocrites.

Model strategy W.B. $\rightarrow$ C is a rhetorical strategy model for developing complex arguments. This model is another model (besides that modelled by Toulmin) as an alternative model that is found to be used in the translation of the Quran text. In this model, a claim or multiple claims are supported by several warrant and backing (Warrant + Backing $\rightarrow$ Claim). In the text of the translation of the Qur'an Albaqarah, model W.B. $\rightarrow$ C used in text development in I8th, 23rd, 28th, 30th, 34th, 36th and 37th curves.

The I8th text of the bow consists of 5 verses, from verse I48 to I52. This I8th bow' contains more of the messages of Allah to the Prophet Muhammad. In verse I48, Allah asserts, each people has a Qiblah in the direction in which they are facing him (according to his inclinations and beliefs). Muslims have a Qiblah set directly by Allah almighty which is the altar in the Mosque, and every people has a Qiblah facing them. Therefore, Muslims compete against others in doing well, so contend for yourselves in goodness. Allah affirming, you will face death wherever you are, Allah almighty will gather you together on the Day of Judgment for Him to give backing/support, and surely Allah will gather you all. Because of Allah almighty know everything.

Verse I49 Allah reiterates wherever you go, whether out of the house at the descent of this verse, or elsewhere, then direct your face towards the Mosque, the Kaaba as a direction in prayer (backing/support). Wherever you (Muhammad) came forth, set your face towards the Mosque, for it is true of your Lord. At the end of this verse, Allah reiterates to all parties both Jews and hypocrites that God is not aware of what you are doing. 
In verse 150 (backing/support), it is reiterated, to eliminate the possibility of misunderstanding arising from verse I49, namely the order to bring your face towards the Mosque, And wherever you are, then set your face towards it, that there may be no reason for the man (except for those who are wrong) among them. This is done so that there is no opportunity for your opponents (Jews and hypocrites) to denounce and mock you (Muhammad). All of them (Jews and unbelievers) are exempted from the presence of the Kaaba because whatever information they give to them (O Muslims), they will still ridicule and denounce. Therefore, says the Almighty, fear them, fear me, that I may bestow my favor upon you, and that you may be guided.

In the verses I5I and I52 (warrant) this verse states that we have turned the Qiblah towards the Mosque to fulfil My favor to you. The fulfillment of the favors is the same as the perfection when Allah sent a Messenger (Muhammad) from among you. The Qur'an and Wisdom (Sunnah), and teach you what you do not know. So remember me, I'll remember you too. Be grateful to me, and do not disobey me.

Model strategy W.B.Q $\rightarrow \mathrm{C}$ is a rhetorical strategy model for developing complex arguments. A claim or multiple claims are supported by several warrant, backing, and supported also by qualifier (Warrant + Backing + Qualifier $\rightarrow$ Claim). In the text of the translation of the Qur'an this letter Albaqarah is a model of W.B.Q $\rightarrow$ C used 5 times (I2.5\%) in the development of texts in the 22nd, 29th, 3Ist, 38th and 39th curves. As an example:

The bowing 22nd text data is a variety of arguments developed with the cause and effect development method by using a complex argument development strategy. In this section, Allah almighty filed two claims namely, I) carrying out qisas (verse: I78) and 2) writing a will (verse: I80). To corroborate his claim, a warrant is stated: I) paragraph: 177 , regarding virtue for the righteous, 2) paragraph: 178 that implementing the qisas must be with provisions and not exceeding limits, 3) paragraph: I79 that through provisions qisas is a guarantee of the survival of humanity.

In connection with the claim of Allah Almighty obliging to write a will, in verse: I8I Allah gives backing/support in the form of condemnation to those who change the will by adding, reducing or hiding the will or the womb after he hears it, and after the contents of the content the will is clear to him..

Then in the execution of this qisas sentence Allah granted the exemption of the qualifier, verse: I78 that when forgiving each other, this qisas sentence should not be enforced. To strengthen that qualifier Allah (backing / support) that Allah
Replacing the sentence with the condition of giving a diat that is not burdensome / beyond measure. Allah also said that such a thing is better and that those who go beyond it will be punished with a painful torment.

Model strategy $\mathrm{V}$ is a rhetorical strategy model for developing complex arguments. A claim or claims are supported by several facts and are also supported by a warrant, backing, and qualifier (Ground + Warrant + Backing + Qualifier $\rightarrow$ Claim). In the translation of the Qur'an text, model V is used 5 times $(12.5 \%)$ in the development of texts in the Ist, 3rd, 2Ith, 24th and 27th curves.

As an example: the Ist bowing text consists of 7 verses, i.e. verses I to 7 . In this section, Allah (speaker) starts the conversation with alif lam mim, Interpreters of this verse interpreted differently, most agreed to interpret this verse as "Allah knows better". In verse 2, Allah (speaker) confirms and assures (claims) to the reader/listener (believers of humans) that the Qur'an has no doubt in it and is used as a guide for those who are pious.

In the next verse, paragraph 3 is explained about the characteristics of those who are responsible as mentioned in verse 2 (ground/fact). This reinforces the statement that the Qur'an is not in doubt for those who fear it because those who fear it are those who believe in the supernatural, perform the prayers, and spend some of their sustenance. Verse 4 reinforces what is stated in the claim that the defendant believed in the Qur'an and the books that were revealed and believed in the hereafter. Verse 5 further affirms that those who feared it were those who received guidance from their Lord and that they were the ones who were fortunate.

In verse 6 and 7, it is explained that unbelievers who have nature or character should be compared to those who fear Allah. These verses reinforce that the Quran is not in doubt for those who fear, but this is not the case for unbelievers (qualifiers) limiting who fear only who do not doubt the truth of the Qur'an, while for those who disbelieve will still doubt. For the disbelievers, they are given a warning or not given was the same, they will not believe in the Holy Qur'an.

Strategy model III is a rhetorical strategy model for developing complex arguments. A claim or several claims are supported by several facts and warrant (Ground + Warrant $\rightarrow$ Claim). In the text of the translation of the Surah Al-Albaqarah model III is used 4 times (10\%) in the development of the text in the 6th, 7th, 9th and I0th curves.

As an example:

The 6th bowing data of text is a variety of arguments using complex argument development strategies. In this book (claim) in verse 48, Allah invites Israel to guard themselves of torture on the 
Day of Judgment. Strengthening the invitation, Allah revealed reasons and facts. The reason (warrant) in paragraph 47, the Children of Israel have been awarded favors of superiority over all nature.

This instruction is strengthened with reasons and facts to corroborate the claim. Ground (fact-I), in verse: 49 , the events that happened to the parents and their ancestors both to the believers are like the story when God Almighty saved the Prophet Moses from the pursuit of Pharaoh. Ground (facts-2), in verse 50, the fact of the event when God Almighty split the sea to save Israel from the pursuit of Pharaoh's army. Ground (facts-3), in paragraphs 5I and 52 by presenting facts in the form of events when Allah Almighty promised the Prophet Moses forty nights and the event when Israel made the calf as an offering and the event when Allah forgave Israel who did wrong. Ground (fact-4), in verse 53, the event when Allah revealed the Book and the Furqon to the Prophet Musa. Ground (fact-5), in verses 54 and 55, when the Prophet Moses invited his people to repent and his people rejected him. Ground (facts-6), verses 56 and 57, when Allah gave the pleasure of life and enjoyment of protection with clouds and food manna and salwa. Ground (fact-7), in verse 58, when Allah commanded Israel to enter and stay in Baitulmaqdis. Ground (fact-8), in verse 59, the event when Allah revealed the punishment in the form of lightning that struck the Children of Israel, people who do wrong/always do wicked, ie those who replace Allah's commands with other commands.

Strategy model I is an argument development strategy model that is classified as simple or complex. One or more claims supported by one or several facts (Ground $\rightarrow$ Claim). In the translation of the Albaqarah claims contained in verses 258, 259, and 260. The claim is supported by several facts revealed in the same paragraph, namely in verses 258,259 , and 260.

The strategy for developing model I was developed in the bowing 35 th. This data in a variety of argument texts developed with a complex argument I development strategy model. This section contains the claim that Allah is Almighty for His Will. As a God who can revive dead creatures and kill living things. To emphasize his almighty nature, the facts conveyed in the form of real stories that happened in the past. These stories are presented to be able to strengthen faith to Allah. The story of the Prophet Ibrahim who argued with King Namrud about the power of God, then the story of someone with a dead city and then with the permission of Allah Almighty, the city came back to life, and the third story about the Prophet Abraham asking God to show power $\mathrm{He}$ revives his dead being. All of these events happened because of Allah almighty can do every thing

The bowing 35th consists of 3 verses, namely verses 258 to 260. Allah expresses the claim that Allah has power in the universe, almighty over everything. To corroborate this claim God presents several facts.

The first fact, namely the events of the past when there was a debate between the Prophet Ibrahim U.S. with King Namrud. Ibrahim was asked to Namrud about his Lord, Ibrahim replied that "My Lord is the one who gives life and causes death." Hearing Ibrahim's answer like that, Namrud also said, "I give life and cause death." Then, Ibrahim said again, "Allah brings up the sun from the east, so bring it up from the west!" Hearing Ibrahim's request like that, confusion of the infidel (Namrud). At the end of the verse, Allah asserts that it does not guide the wrongdoers. This is as expressed in the verse, do not you pay attention to those who argue with Abraham about his Lord, because Allah has given him a kingdom (power). When Ibrahim said, "My Lord is the one who turns on and off," he said: "I can turn on and off." Ibrahim said, "Allah has issued the sun from the east, then he has risen from the west." Then the confusion of the infidel. Allah did not give instructions to the wrongdoers.

The second fact, in this verse 259 Allah gave a story about someone who travelled through a country, the state of the country when through its building collapsed to cover the roofs have been destroyed. Seeing such conditions, he said, "How did Allah revive this country?" After that, Allah Almighty killed him for a hundred years, then resurrected him (brought him back to life). Then Allah asked the person, "How long have you lived here?" The person replied, "I stay here for a day or half a day." Allah ensures that he has been in that place for one hundred years.

Then Allah commanded him, "Look at the food and drinks that have not changed, (the food is not stale and not reduced from before). If that's the case, it's not wrong if he says more or less a day he was in that place. But the command of Allah Almighty "look at your blood!" He was dead (not just a moment ago), but already a hundred years ago, it was proven that he had become bones. Allah said, "We reconstructed the donkey, then we wrapped it with flesh," then arose (living) the donkey as it was before its death.

This event was shown by God to be evidence for humans, that is, people who were killed a hundred years and revived were the power of Allah, that is, for people who lived after the land they rebuilt. This incident was then said, "I know that Allah is almighty over everything 
The third fact stated in verse: 260. Allah Almighty shows His other power that gives life and causes death his creatures and defends and support those who believe. It starts with the story when the Prophet Ibrahim told his Lord to show him how God can raise people who are dead. The Prophet Ibrahim, God said whether you (Ibrahim) do not believe. The Prophet Ibrahim also answered that he believed. However, to be able to strengthen his belief, he asked God to show how God raised the dead. At Ibrahim's request, Allah said and ordered Ibrahim to take a bird, then the bird asked him to be chopped. After that, part of the limb of the chopped bird is placed on a hill and the other part of the chopped member of the bird's body is placed on another hill. Then, Allah asked Ibrahim to summon the bird and with his approval, the bird would come and approach the Prophet, Ibrahim. This verse then closes with the statement of God's authority that He is the Almighty, the All-Wise.

Strategy model II is a rhetorical strategy model for developing complex arguments. Some claims are supported by several facts which also claim (Ground$\mathrm{n} \rightarrow$ Claim-n). The translation of the Albaqarah model II is used in the development of the text in the 'I5th bowing.

Text bowing 15 th is a variety of arguments developed with complex argument development strategies. In this section, Allah stated (claim-I) reminds Israel of their blessings. God bestowed upon them advantages compared to other people at that time (verse: I22). Inviting Israel (claim-2) to fear the Day of Judgment (verse: I23). In this section, Allah reminds (verse: 125) of humanity to take lessons on events when Allah made the Kaaba as a place of prayer (claim-3). For this reason, Allah Almighty stated events (ground/facts) to be used as lessons, namely the story of the journey and struggle of the Prophet Ibrahim in undergoing and receiving tests from his Lord (verses: I24 and 125). Prayers are offered by Prophet Ibrahim and supported by the reasons Allah Almighty puts forth at the end of verse 126, (ground/fact).

Strategy model W.R. $\rightarrow \mathrm{C}$ is a rhetorical strategy for developing complex argument models. A claim or claims are supported by several warrants and supported by rebuttal (Warrant + Rebuttal $\rightarrow$ Claim). In the text translation of surah Albaqarah model W.R. $\rightarrow$ C is used one time $(2.5 \%)$ in the development of the text in the 5th book.

Bowing 5th data text is a variety of arguments developed by the complex argument development strategies. Allah Almighty commands (claim-I) the Israel (Jews) to remember the favours of Allah, fulfil promises to Allah, and fear Allah (verse: 40).
Commands (claim-2) have faith in the Koran, the prohibition of becoming infidels and selling the verses of Allah at a cheap price (verse: 4I). Prohibition (claim-3) confuses truth with ignorance and prohibits hiding the truth (verse: 42). The order (claim-4) performs salat, zakat and bowing (verse: 43). God asks rhetorically in the form of conflicting conditions (rebuttal) (verse: 44). Claim-5 is the command only to Allah to ask for help patiently and perform prayers (verse: 45). Warrant, Allah gives the reason that all their actions will be accountable to their Lord on the Day of Judgment (verse: 46). The $\mathrm{W} \rightarrow \mathrm{C}$ strategy model is a rhetorical strategy model for developing complex arguments. This model is another model found in text usage. In this model, a claim or multiple claims are supported by several warrants (Warrant $\rightarrow$ Claim). In the text of the translation of the Qur'an Albaqarah, the $\mathrm{W} \rightarrow \mathrm{C}$ model is used in the development of the text in the I3th chapter

The I3th bowing text data in a variety of argumentation models for developing complex argument strategies. In this bowing Allah convinced the Muslims (Prophet Muhammad and his people) about the truth of Islam and the Quran. To undermine that belief, Allah gave the reason of a story that illustrates the bad behavior of the Jews and Christians. They try to shake the faith of Muslims, Allah asserts that their actions and words are wrong.

The bowing 13th text consists of 9 verses, from verses I04 to II2. In the previous bowing has explained about the ugliness of Israel (Jews) in the early days of the decline of Quran. This section contains more of Allah's advice to the Muslims (people who believe), this advice is still associated with the bad behavior of the Jews. As revealed in verse I04 (claim-I) O believers! Do not say "Raa'ina", but say: "Unzhurna", and listen. The disbelievers will get painful punishment. The word Raa'ina is a word commonly spoken by Israel (Jews) which means "pay attention to our condition or ability "when the word of God is delivered from the prophet. The word raa'ina has a negative, mocking tone. Actually, in terms of the meaning of the word raa'ina is the same as the meaning of the word unzhurna. However, the word unzurna has a positive connotation to Muslims to choose to use the word unzurna.

In verse I05 Allah reminds (claim-2) that Muslims should not trust friendship with the people of the book, that is, those who have bad qualities as mentioned earlier. It is revealed in this verse that they (the disbelievers of the People of the Book) are jealous of the goodness Allah gave to the Muslims. Allah confirms that giving His mercy to the people $\mathrm{He}$ wants, namely the Muslims. 
In verses 106 and 107, Allah confirms to the Jews who do not believe and doubt the truth of the Qur'an (actually to confirm the faith of the Muslims for the resistance made by the People of the Book of the Jews and Christians). Allah Almighty denies and corrects the Jewish view which says that Allah cannot change his laws (verses in the previous book) with new laws. Allah Almighty says in this verse that $\mathrm{He}$ does not eliminate or cancel the laws that have been applied in the previous books, except to replace them with something better or comparable to him (warrant-I).

In verse 108, Allah exhorts (claim-3) Muslims do not follow the bad deeds of Israel who ask things that are not natural to their prophet. This statement is followed by Allah's confirmation that those who are replacing faith with disbelief then truly he has strayed from the straight path. In this verse I09, Allah warns (claim-4) of many Muslims among the People of the Book (Jews and Christians) who always try to divert Muslims from their religion to disbelief, or try to instil doubt in themselves Muslims about the truth of their religion and the truth of the Qur'an. Allah confirms that all of them (Jews and Christians) do because of the nature of jealousy that arises from within themselves after seeing the truth of Islam. Allah also reminded Muslims to

\section{Conclusion}

The most widely used rhetorical strategy model in the text of the translation of the Qur'an Albaqarah is the development strategy model IV (W.B $\rightarrow$ C). The strategy is used I5 times or $37.5 \%$ of the total 40 data. The second rhetorical strategy model that is widely used is an alternative model. Model W.B $\rightarrow$ C used 7 times or $17.5 \%$. The next strategy model that is also widely used is an alternative model W.B.Q $\rightarrow$ C and model $\mathrm{V}$ each was used 5 times (I2.5\%). Next is the strategy development model III $(\mathrm{G}+\mathrm{W} \rightarrow \mathrm{C})$, used 4 times or by I0\% and model I $(\mathrm{G} \rightarrow \mathrm{C})$, model II (G-n $\rightarrow$ C-n), model W $\rightarrow$ C, and model W.R $\rightarrow$ C each used I time or $2.5 \%$ each.

The rhetorical strategy in submitting all claims (100\%) uses a complex strategy. A claim or more is not only supported by one fact. However, one or more claims are supported by more than one fact, both are parallel and not parallel. There are even some facts and data (ground), reinforced by justification or validation of data (warrant), reinforced with another carrying capacity (backing support) to strengthen one or more claims..

Allah swt in delivering commands, invitations, prohibitions, and even challenges were based on complex arguments and equipped with supporting forgive and be tolerant (not reciprocate) for their treatment

In verse II0 Allah invites (claim-5) the Muslims to perform the prayers, perform their zakat and remind them that whatever good Muslims do will bring good for themselves and also get merit from Allah because Allah sees what His people do.

In verse III Allah strengthens the faith of the Muslims by reminding the behavior of the Jews and Christians towards the Muslims. They said that heaven is for Jews and Christians, not for Muslims. The words of the Jews and Christians were denied by Allah Almighty by saying that it was only their imagination. Even Allah Almighty challenges them to show proof of their truth that they are righteous (warrant-2).

In verse II2, Allah affirms the Muslims that this is not the case, unlike the Jewish and Christian infidels, but Allah confirms that whosoever surrenders fully to Him and does good then Allah will reward and not be overcome by fear and not grieve (warrant-3).

facts. It has implications for speakers both oral and written should consider the importance of using complex arguments, likewise in learning the ability to write and speak, is necessary to write complex arguments by the presentation of relevant facts. It is very important to be mastered by students and students.

\section{Politeness}

The authors thank Professor Zainal Rafli and Professor Emzir who have guided the authors in this study.

\section{Referensi}

Duke, R. K. (1990). A Rhetorical Analysis. In D. M. Gunn (Ed.), The Almond Press (25th ed., Vol. 46). https://doi.org/I0.II63/I570063II2340I2I

Herrick, J. A. (2017). The History and Theory of Rhetoric (6th ed.). New York: Routledge.

Ibrahim, Z., Ibrāhīm, Z., Ibrahim, Z., Aydelott, S. T., \& Kassabgy, N. (2000). Diversity in Language: Contrastive Studies in Arabic and English Theoretical 
and Applied Linguistics. American Univ in Cairo Press.

James M. McCrimmon (I992) Writing With a Purpose. Eighth Edi. United States: Houhton Mifflin Company.

Krippendorff, K. (2013). Content Analysis: An Introduction to Its Methodology (Second Edi, Vol.53).https://doi.org/I0.1017/CBO978I 1074 I5324.004

Kurylo, A. (2012). Inter/cultural communication: Representation and construction of culture. Sage Publications.

Leaman, O. (2006) The Qur'an: an Encyclopedia. First, Iran and the Caucasus. First. Edited by O. Leaman. New York USA: Routledge. doi: IO.I I63/I573384I0xI27434I9I89784.

Mayring, P. (2004). Qualitative ontent analysis. In A companion to qualitative research (Vol. I).

Murthy, D. M., \& Ghosal, M. (20I4). A study on Aristotle's rhetoric. Research Journal of English
Language and Literature, A Peer Reviewed Int. Journal, 2(4).

Nelson, K. (200I). The art of reciting the Qur'an. American Univ in Cairo Press.

Opiyo-Omolo, B. (2004). The continuum complete international encyclopedia of sexuality. A\&C Black.

Shihab, M. Q. (I996) 'Wawasan Al-Qur'an Tafsir Maudhu'I atas Pelbagai Persoalan Umat', Wawasan Al-Qur'an Tafsir Maudhu'I atas Pelbagai Persoalan Umat, (November), p. 453. Available at: https://www.academia.edu/6037537/WAWASA N_AL-QURAN_quraish_shihab.

Tessuto, G., Bhatia, V. K., \& Engberg, J. (2019). Frameworks for Discursive Actions and Practices of the Law. Cambridge Scholars Publishing.

Warnick, B. (200I) Critical Literacy in A Digital Era, Critical Literacy in A Digital Era. New York: Macmillan Publishing Company. doi: I0.4324/978I4I0603838. 